\title{
心理的ストレス概念に基づく歩行行動のモデル化 MODELING OF PEDESTRIAN BEHAVIOR BASED ON MENTAL STRESS
}

\author{
大佛 俊 泰*, 佐 藤 航** \\ Toshihiro OSARAGI and Wataru SATO
}

\begin{abstract}
A computer simulation of pedestrian flow is an effective method for examining relationships between pedestrian space and pedestrian behavior within that space. However, the characteristics of pedestrian behavior are not fully modeled in earlier studies. In this paper, a model describing pedestrian behavior is proposed by utilizing the concept of mental stress. Unknown parameters of the model are estimated using observed data from real pedestrian behavior. The estimated model can describe the differences of pedestrian behavior according to walkers' characteristics. Through some of the simulations in the proposed model, we can examine comfort or safety of pedestrian flows within crowded pedestrian areas.
\end{abstract}

Keywords: pedestrian space, pedestrian behavior, mental stress, simulation 歩行空間, 歩行特性, 心理的ストレス, シミュレーション

\section{1.はじめに}

歩行空間における群集流動について理解を深めることは歩行空 間設計を行う上で重要である。群集流動のコンピュータ・シミュ レーションは, 建築空間と人間行動の対応関係を明らかにするため の有効な方法と考えられる。そのため,その基礎となる歩行者行動 のモデル化に関する研究は今までに多くなされてきた。国内では 中文1)や岡崎文2)，文3)が早い時期に優れた研究を行っている。岡崎の 研究では, 歩行者間に作用する目に見えない力を磁気に見立てると いうユニークな視点から，いわゆる磁気モデルを提案している。そ の後, 建部ら文4), 文5) は, 歩行者の個体領域, 歩行者の移動, 障害物 の移動予測という 3 つの要因から歩行者の回避行動をモデル化 し，さらに，観測データをもとに回避行動開始点における回避距離 を推定している。一方,こうした基礎的な研究とコンピュー夕技術 の進展を背景として, 歩行シミュレーションの研究も行われるよう になった。例えば，岡崎・松下文6)の避難シミュレーションの研究 や，矢守・杉万文7)による横断歩道における群集流動パターンのシ ミュレーションがある。海外では，交通計画におけるNetwork Model を応用して, 歩行者を質点と捉えたTimmsらのモデル文8) が ある。しかし，歩行者は全て一様に扱われていており，歩行者ごと に異なる歩行特性は表現されていない。そのため，Kerrideら
文9）は，セルラーオートマトンを応用して，歩行特性を記述す るパラメータを歩行者ごとに設定したモデルを構築している。 しかし，パラメータは経験則から設定されており，実デー夕 から推定されていない。

パーソナルスペースと呼ばれる概念が存在するように, 歩行者は 他者が自分に近づくことである種の心理的ストレスを感じている。 本研究では, 歩行者の回避行動はこのような心理的ストレスを低減 させる方向へ行っていると考え, 速度や方向をダイナミックに変化 させながら回避行動を連続的に繰り返している群集流動における歩 行者の挙動を記述する。さらに, 群集流動の観測デー夕を用いて歩 行モデルのパラメー夕推定を行い歩行特性を抽出し, 歩行特性に影 響を及ほす要因について検討する。さらに，このモデルを用いてシ ミュレーション実験を行い, 快適性や効率性の視点から歩行空間の 環境評価を試みる。

\section{2. 歩行モデルの榗築}

\section{1 歩行モデルの特徵}

本研究で提案する歩行モデルの特徵とモデル化の方法を図 1 に 示した。本モデルは, 歩行者の挙動を歩行時に受けるストレスで表 現している点に特徴がある。歩行時のストレスは歩行者属性・環境

\footnotetext{
$*$ 東京工業大学大学院情報理工学研究科 助教授・博士 (工学)

Assoc. Prof., Graduate School of Information Science and Engineering, Tokyo Institute of Technology, Dr. Eng.

** 東京工業大学大学院情報理工学研究科 大学院生 


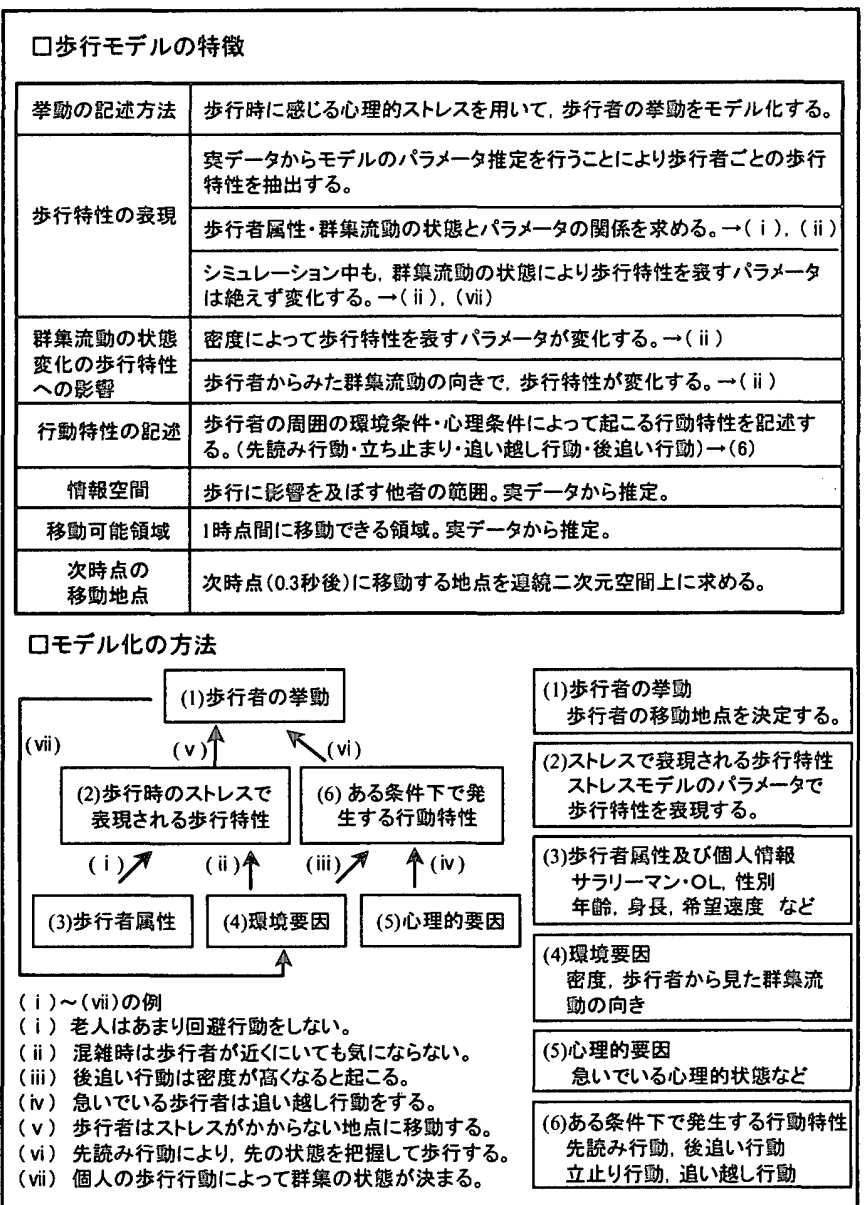

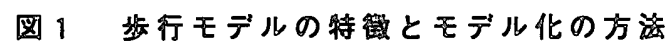

要因・心理的要因から説明される。さらに, 個人の挙動は群集流動 の状態を構成し，これが環境要因となって個人の挙動を規定すると いう循環型のモデルになっている。

\section{2 ストレス概念を用いた歩行の記述}

\subsection{1 歩行時に受けるストレスの定程}

歩行者は歩行中に心理的ストレスを感じながら歩行している。例 えば，歩行者は他者が近くにくるとその歩行者から心理的ストレス を感じる（以下，「他者ストレス」)。また，歩行者は目的地を持っ ており, 目的地への最短経路上の次時点における移動地点(以下, 希望到達地点)からずれるとストレスを感じる（以下，「目的地ス トレス」)。そこで,これら二つのストレス概念を用いて，歩行者の 挙動をモデル化することを試みた。具体的には，他者ストレスと目 的地ストレスを足し合わせた心理的ストレスを求め, ストレスの最 も低い地点に歩行者は移動すると考えた（図 2)。

\subsection{2 ストレス関数のバリエーション}

歩行者が受けるストレスを表現するための適切な関数を選ぶこ とは, 歩行者の挙動を記述する上で重要である。そこで, ストレス の関数型について検討し（図 3 参照），「他者ストレスの関数」+ 「目的地ストレスの関数」の組み合わせとして, (1) 指数型+票数 型, (2) 幕数型+赛数型, (3) 指数型十指数型, (4) 幕数型+指数型 という 4 種類のモデルを考えた。まず, 他者ストレスについて考 えると, 他者の位置が最大值となる距離聥減関数となる（図 3 (a)）。次に, 目的地ストレスについて考えると, 多少希望到達地点

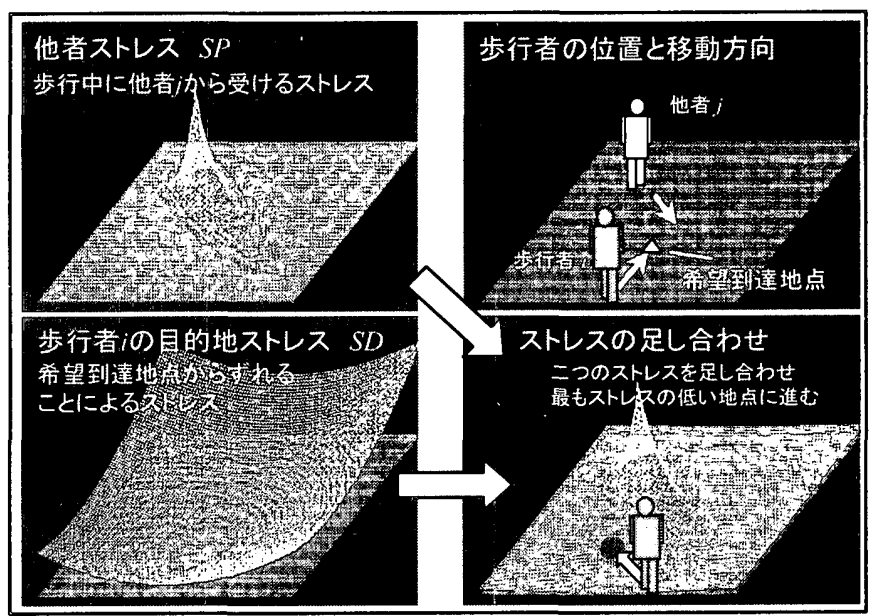

图 2 ストレス概念を用いた歩行の記述

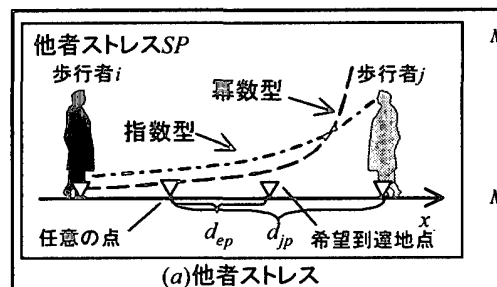

Model (1) 指数型 十露数型

Stress $=\sum S P_{i}+S D$

$=\sum_{j} \exp \left(-\alpha_{1} \cdot d_{j p}\right)+\gamma\left(\frac{d_{t p}}{V_{w}}\right)^{\alpha_{2}}$

Model (2) 軍数型 十軍数型

Stress $=\sum d_{j p}{ }^{-\alpha_{1}}+\gamma\left(\frac{d_{e p}}{V_{w}}\right)^{\alpha_{2}}$

Model (3) 指数型 十指数型

目的地ストレス $S D$ (指数型)

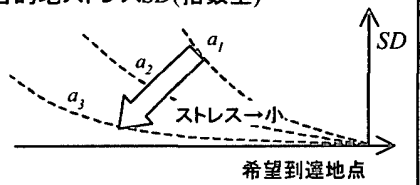

Stress $=\sum \exp \left(-\alpha_{1} \cdot d_{j p}\right)$

$\sum_{j} \exp \left(\exp \left(-\alpha_{2}\right) \cdot d_{e p}\right)$

Model (4) 窑数型 +指数型

Stress $=\sum d_{j p}{ }^{-\alpha_{1}}+\exp \left(\exp \left(-\alpha_{2}\right) \cdot d_{e p}\right)$
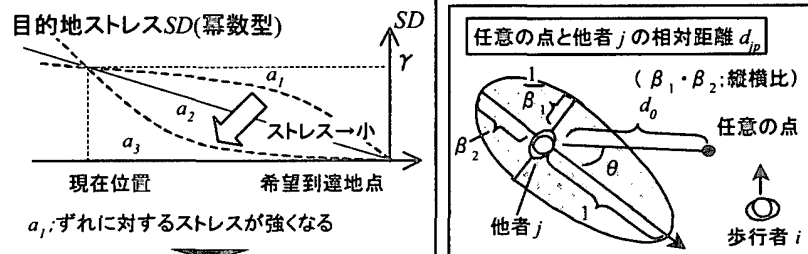

$a_{1}$ : 林れに対するストレスが強くなる

$a_{3}$;多少ずれてもストレスを感しない

(b)目的地ストレス

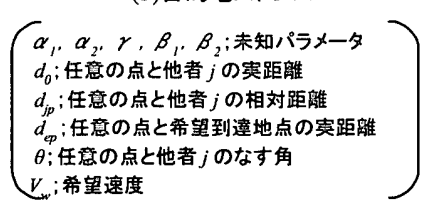

他者 が発するストレスは進行方向能方 に大きくなっていると考えられる。そこで 相対距踓 $d_{i}$ を縦横比 $\beta_{1} ， \beta_{2}$ を用いて以 下のように設定する。

if $\cos \theta>0$ then

$d_{j p}=\sqrt{\left(d_{0} \beta_{1} \sin \theta\right)^{2}+\left(d_{0} \cos \theta\right)^{2}}$

if $\cos \theta<0$ then

$d_{j p}=\sqrt{\left(d_{0} \beta_{1} \sin \theta\right)^{2}+\left(d_{0} \cos \theta / \beta_{2}\right)^{2}}$

圆3ストレス関数のバリエーション

からずれてもあまりストレスを感じない歩行者や，少しずれるだけ で強いストレスを感じる歩行者もいる。このような個人の歩行特性 はパラメータの值によって表現される（図 $3(\mathrm{~b})$ )。

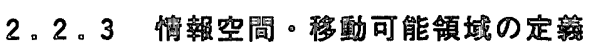

歩行者はすべての他者を意識して歩行しているとは考えられず， また，あまりにも多くの他者を考慮に入れるとコンピュータ・シミ ユレーションを行う際にも, 計算量の問題が生じる。そこで, 歩行 者が歩行時に周囲の歩行者を認識する範囲を「情報空間」と呼び， この範囲内の歩行者からストレスの影響を受けるものとする。ま た, 歩行者が次の時点までに移動できる範囲を「移動可能領域」と 呼び，この範囲内に次時点の移動地点が決まるものとする（図 4)。 具体的な数值は後述する観測データをもとに設定している注1), 注2)。 


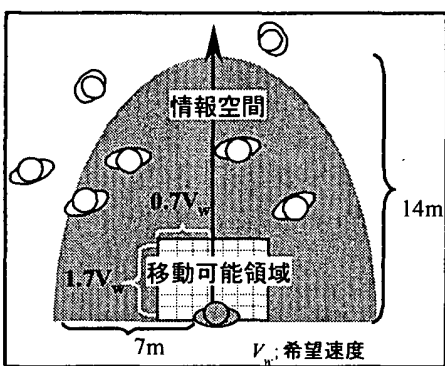

図 4 情報空間・移動可能項域

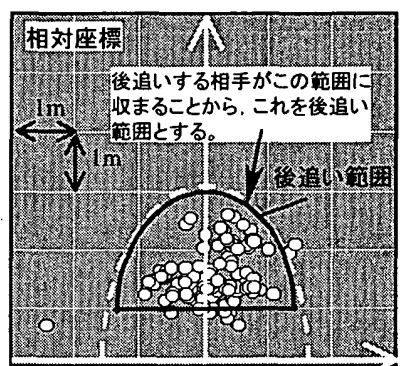

図 5 後追い箅囲

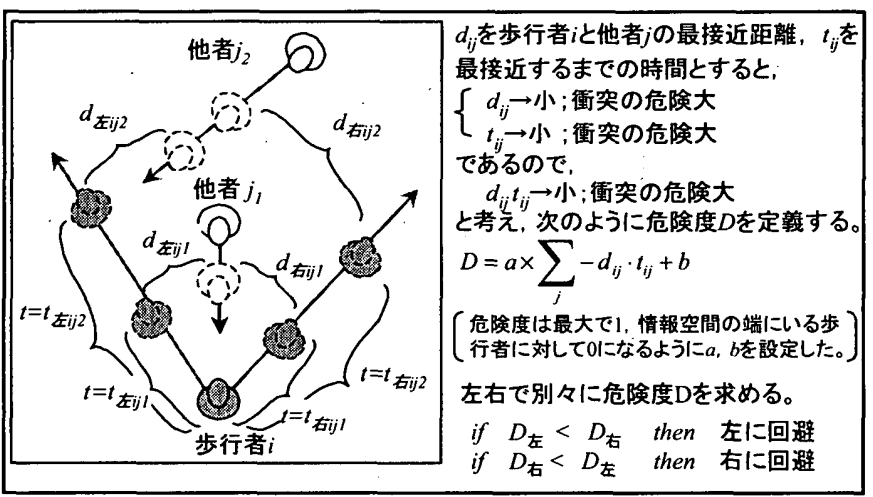

図 6 先読み行動の記述

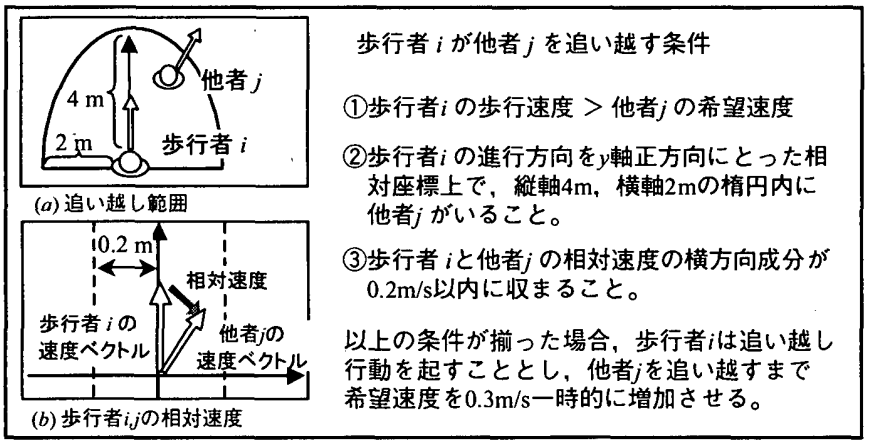

図 7 追い越し行動の記述

\section{3 ある条件下で発生する行動特性の組み込み}

歩行者の挙動を観察すると,ストレスとは別の要因に依存する行 動特性が考えられる。これらの行動特性は, 以下に示すようにスト レスとは別の方法で表現し，モジュールとしてモデルに組み込む。

\subsection{1 先読み行動}

群集流動の中で, 歩行者は効率的に目的地にたどり着くために絶 えず先の状態を予測しながら歩行している。これは，目の前の歩行 者を回避する方向（右または左）はその後の歩行効率に大きく影響 するためである。そこで, 回避行動時の先読み行動の記述方法につ いて考える。先読み行動は後続の他者を含めた周囲の歩行者との衝 突を事前に回避する行動と解釈することができる。そこで, 衝突の 危険を測る尺度を図 6 に示す方法で構成し，これをもとに先読み 行動を記述した。

\section{3 . 2 立ち止まり行動}

入り乱れた歩行流では，目の前の歩行者が通り過ぎるのを待つた めに何度も立ち止る。観測デー夕を用いて子細に検討すると，次時 点 $(0.3$ 秒後 $)$ に $30 \mathrm{~cm}$ 以内に移動するような挙動はほとんど見ら れない。そこで,この範囲 $(30 \mathrm{~cm}$ 以内）を立ち止り範囲とし，次

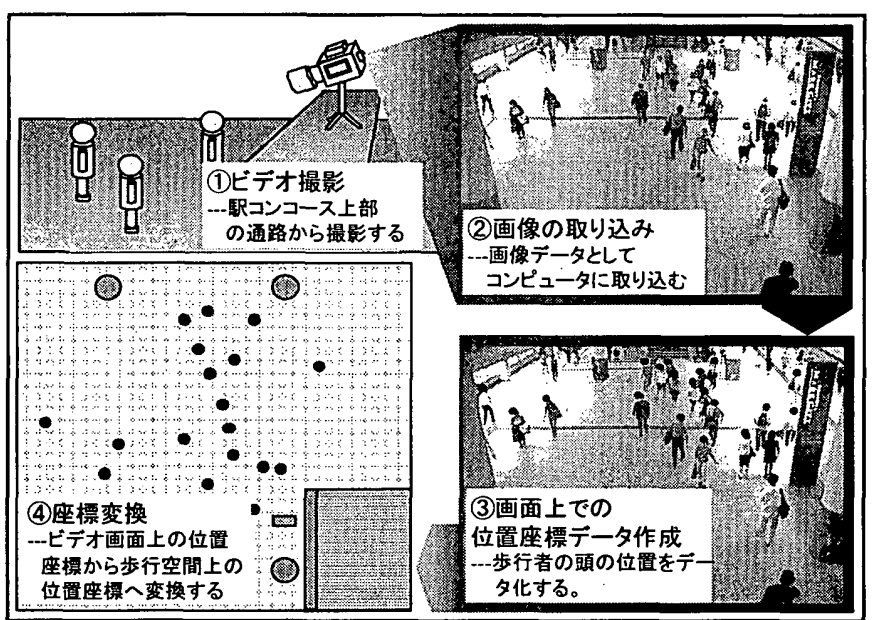

图 8、データの作成

時点の移動地点がこの範囲内に求まっても，歩行者は進まずにその 場に立ち止るものとする注3。

\section{3 .3 後追い行動}

密度上昇に伴い, 歩行者は同方向に進む歩行者の後を意識的に追 って歩行する。観測によれば，(1)図 5 に点線で示した棈円内に他者 が 2 人以上いる密度で, また, (2)図 5 に太線で示した後追い範囲内 で同方向に進む歩行者の後を追って，後追い行動が発生していた。 そこで, 両条件が揃うとき，後追い行動を起こすものと考える。

\subsection{4 追い越し行動}

歩行者の追い越し行動は「後追い $\rightarrow$ 速度上昇 $\rightarrow$ 追い越し」とい うプロセスからなる文10)。そこで, 歩行者は図 7 に示す条件を満た すとき，追い越し行動を開始する(追い越し開始時点)と考えた注4)。 どのような方法で速度の增加を表現するかが重要になるが，ここで は希望速度を一時的に増加させることで表現した。希望速度の増加 量は観測データをもとに $0.3 \mathrm{~m} / \mathrm{s}$ とし, 追い越す相手の真横を通過 する時点（追い越し完了時点）まで継続するものと考えた。

\section{3. 歩行者データの作成と歩行ストレスモデルの推定}

\section{1 歩行者の時系列データの作成}

駅コンコースにおいて撮影したビデオ映像から歩行者のビデオ 画面上での座標デー夕を作成し，これに座標変換を施すことで, 歩 行者の時系列位置座標データを作成した注5)(図8)。計測誤差は，ビ デオ撮影地点からみて縦方向で士 $10 \mathrm{~cm}$, 横方向で $\pm 5 \mathrm{~cm}$ 以内に収 まることを確認した。デー夕作成の具体的な方法とその精度につい ては朝田・大佛文11)，文12)を参照されたい。

\section{2 パラメータ推定}

\subsection{1 パラメータ推定の結果とストレス関数の選定}

観測から得られた実際の歩行軌跡を当該歩行者にとってのスト レス最小地点と考え，パラメータ推定を行った。具体的には，モデ ル上でのストレス最小地点と実際の歩行軌跡との距離自乗和が最小 になるように，勾配法を用いてパラメータを推定した（サンプル数 は40)。表1に各ストレス関数ごとの推定結果の一部を示してある。 また, 表 1 の右端に実際に移動した軌跡と推定された軌跡の位置の ずれの平均值（距離誤差）を示してある。

各歩行者の距離誤差をみると, 各モデルとも 1 時点平均で $10 \mathrm{~cm}$ 
表 1 ストレス関数別のパラメータの推定結果

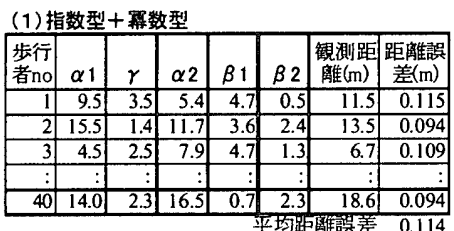

(3) 指数型十指数型

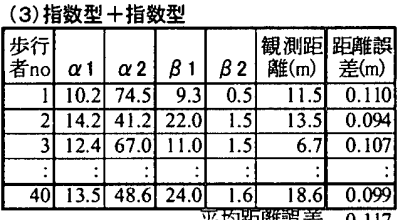

(2) 烡数型+霖数型

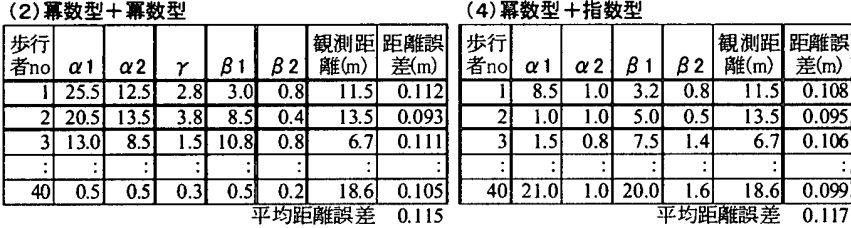

他者と向かい合うて同一直線状を接近する埸合のストレスを, $x$ 方向の一次元空 間で考える。

$\operatorname{Stress}\left(x_{p}\right)=\exp \left(-\alpha_{1} \cdot d_{j p}\right)+\exp \left(\exp \left(-\alpha_{2}\right) d_{c p}\right)=\exp \left\{-\alpha_{1}\left(x_{j}-x_{p}\right)\right\}+\exp \left\{\exp \left(-\alpha_{2}\right)\left(x_{e}-x_{p}\right)\right\}$

ここで, $\frac{\partial \operatorname{stress}\left(x_{p}\right)}{\partial x_{p}}=0$ となる点, すなわち、

ストレス最小点 $x_{p \min }$ を求める。ここで,

右図のように, $x=x$ となるときの

両者間の距離が他者 $j$ に近づける限

界距離となることに注意すると，両

者間の距離（限界距離）

$D_{a \text { 正面 }}=\left(x_{j}-x_{i}\right)$ は次式で得られる。

$D_{a \text { 正面 }}=-\frac{1}{\alpha_{1}} \log \left(\frac{\exp \left(-\alpha_{2}\right)}{\alpha_{1}}\right)-\frac{\exp \left(-\alpha_{2}\right)}{\alpha_{1}} V_{w}$

$=\frac{\alpha_{2}}{\alpha_{1}}+\frac{\log \left(\alpha_{1}\right)}{\alpha_{1}}-\frac{\exp \left(-\alpha_{2}\right)}{\alpha_{1}} V_{w}$

ここで，第二項以降は表2に示すように 非常に小さい值となるため，以下の近 似が成立する。

$D_{a \text { 正面 }} \frac{\alpha_{2}}{\alpha_{1}} \quad$ （他者の正面に近づける限界距離）
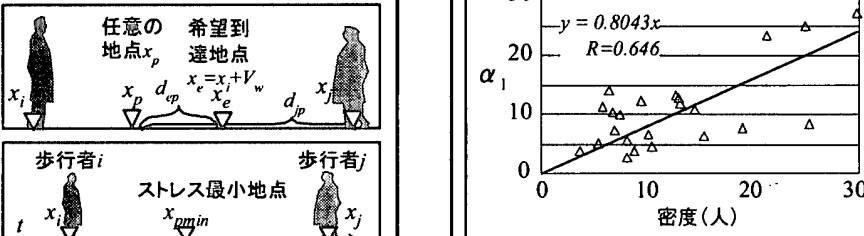
ススの影製は小くなる。

一男性は女性に比へ密度が上昇しても $\alpha$ が小 さく、遠方に注意を払って歩行することがわか ・相関係数は1\%水準で有意である。

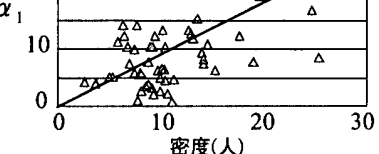

※密度は情報空間内の他者数で表している。
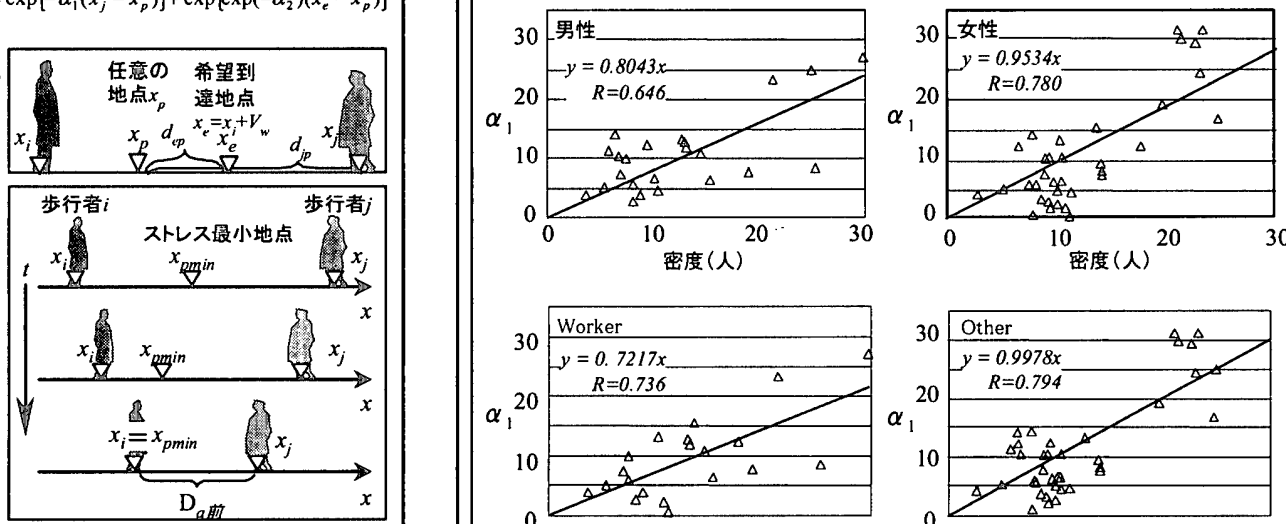

$\alpha_{1}$ : 他者ストレスのパラメータ

$\alpha_{2}:$ 目的地ストレスのパラメータ $\mathrm{V}_{\mathrm{w}}$ : 希望速度(一時点間に進む距離)

同様に，他者と同一方向に進行している場合の限界距離，およぴ 横方向の限界距離を求めることができる。

$D_{\text {a事) } j} \fallingdotseq \frac{\beta_{2} \alpha_{2}}{\alpha_{1}}$ (他者の後方に近づける限界距離)

$D_{a f ⿱_{2}} \doteqdot \frac{\alpha_{2}}{\beta_{1} \alpha_{1}} \quad$ （他者の横方向に近づける限界距離）

図 9 限界距離とパラメータの関係

前後のずれに収まっており，全歩行者の平均をみても，同程度に記 述力は高いことがわかる。ただし，(3) 指数型十指数型はパラメー 夕数が少なく簡潔なモデルであり，また，他者ストレス，目的地ス トレスの関数型が同じであることから，以下に示すようにパラメー 夕の解釈が容易となる。これらの理由から，(3) 指数型+指数型を ストレス関数として採用することとした。

\subsection{2 限界距離}

歩行モデルでは, 歩行者はストレスが最小となる地点へ移動する ものと考えている。そこで，ストレスが最小となる地点をパラメー タで表現し，これを用いて歩行者 $i$ が他者 $j に$ 近づける限界距離を 求めた（図 9)。この值は歩行者 $i$ にうて, 他者の進入を許さない 領域の限界を示しており，一種のパーソナルスペースの大きさと考 えることができる。すなわち，パーソナルスペースのおおよその広 がりをモデルのパラメータで表現することができる。
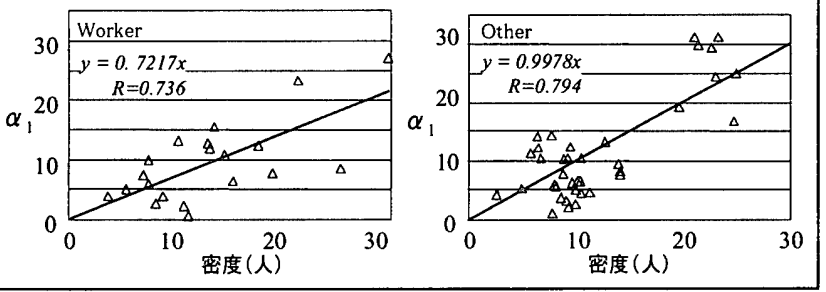

(a) $\alpha$, と歩行者属性·摆境情報の関係
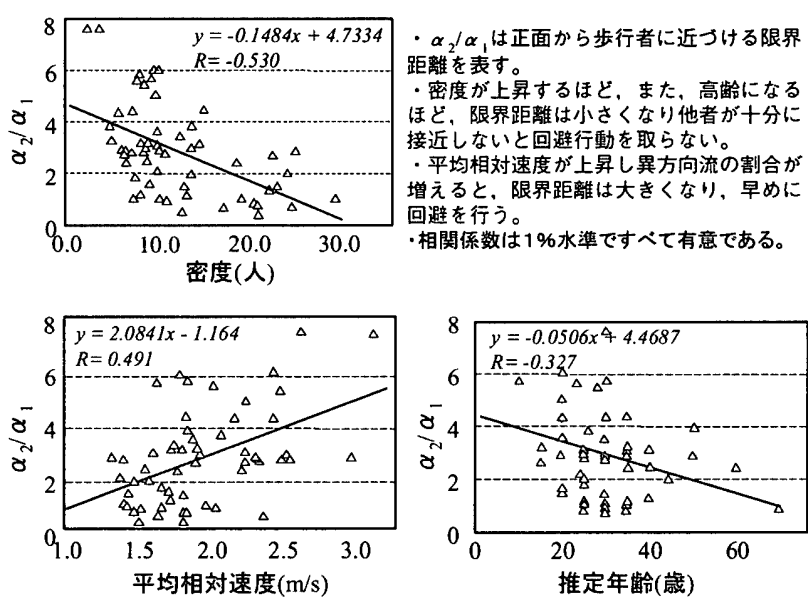

(b) 限界距離と歩行者属性·環境情報の関係

\section{図11 步行者属性から見た歩行特性}

\section{3 。3 步行者属性と步行特性}

\subsection{1 歯行者属性からみた步行特性}

モデルの未知パラメータを安定的に推定するため, 先に用いてい たデータに新しく観測テータを追加してパラメータを推定した（サ ンプル数は 57)。次に，推定パラメータと歩行者属性・環境情報の 関係について考察した。ここでは歩行者属性として, 性別・worker

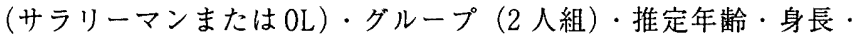


表 2 パラメータの構造化

\begin{tabular}{|c|c|c|c|c|c|c|c|c|c|}
\hline \multicolumn{3}{|c|}{$\begin{array}{l}\text { (1) } \alpha \text { の重回㷌結果 } \\
\text { 重相関係数 }=0.775\end{array}$} & \multicolumn{2}{|c|}{$\begin{array}{r}* * 1 \% \text { 有意 } \\
* 5 \% \text { 有意 }\end{array}$} & \multicolumn{5}{|c|}{$\begin{array}{l}\text { (2)対向者に近づける限界距離 } \alpha_{\alpha_{4}} \\
\text { 重相関係数 }=0.6962\end{array}$} \\
\hline 变数名 & \begin{tabular}{|l} 
偏回㥜 \\
係数
\end{tabular} & \begin{tabular}{|l} 
標染偏 \\
回㛿係数
\end{tabular} & $\mathrm{t}$ 値 & 判定 & 桨数名 & \begin{tabular}{|l} 
偏回㷌 \\
係数
\end{tabular} & $\begin{array}{l}\text { 檟準偏 } \\
\text { 回㛿係数 }\end{array}$ & t t值 & 判定 \\
\hline worker & -0.285 & -0.2702 & 2.89 & $* *$ & $\begin{array}{l}\text { 平均相対 } \\
\text { 速度 }\end{array}$ & 1.75 & 0.412 & 3.77 & ** \\
\hline 密度 & 1.070 & 0.8447 & 9.04 & ** & 推定年龄 & -0.03 & -0.167 & 1.57 & \\
\hline 定数項 & -1.089 & & 0.72 & & worker & -0.04 & -0.185 & 1.36 & \\
\hline \multirow{3}{*}{\multicolumn{5}{|c|}{$\begin{array}{l}\text { (3)横方向の限界距離 } \frac{\alpha_{2}}{\beta_{1} \alpha_{1}} \\
\text { 重相関係数 }=0.5909\end{array}$}} & 密度 & -0.10 & -0.345 & 2.78 & ** \\
\hline & & & & & 男性 & 0.01 & 0.047 & 0.32 & \\
\hline & & & & & 定数項 & 1.65 & & 1.44 & \\
\hline 変数名 & $\begin{array}{c}\text { 偏回㛿 } \\
\text { 係数 }\end{array}$ & \begin{tabular}{|c|} 
翼準偏 \\
回惯係数
\end{tabular} & $\mathrm{t}$ 值 & 判定 & \multirow{2}{*}{\multicolumn{5}{|c|}{$\begin{array}{l}\text { (4)他者の後方に近つけする限界距離 } \frac{\beta_{2} \alpha_{2}}{\alpha_{1}} \\
\text { 重相関係数 }=0.6596\end{array}$}} \\
\hline 希望速度 & 0.134 & 0.2251 & 1.90 & & & & & & \\
\hline 推定年齢 & -0.002 & -0.1727 & 1.48 & & 変数名 & 偏回帰 & \begin{tabular}{|c|} 
標準偏 \\
\end{tabular} & t値 & 判定 \\
\hline 身長 & 0.348 & 0.3540 & 2.75 & *** & worker & -0.07 & $\begin{array}{c}-0.288 \\
-0.28 x\end{array}$ & 2.50 & * \\
\hline 密度 & -0.009 & -0.4220 & 3.20 & ** & 平均相対 & & & & \\
\hline 定数項 & -0.357 & & 1.92 & & 速度 & 1.38 & 0.323 & 3.00 & *** \\
\hline \multirow{3}{*}{\multicolumn{5}{|c|}{ 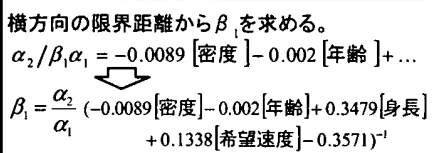 }} & \begin{tabular}{|l|} 
密度 \\
\end{tabular} & -0.10 & -0.368 & 3.15 & ** \\
\hline & & & & & 定数項 & 1.54 & & 1.45 & \\
\hline & & & & & $\beta_{2}=\frac{\alpha_{1}}{\alpha}$ & & . & .10 & 密度 \\
\hline
\end{tabular}

希望速度を用いた。また, 環境情報として密度・群集流動の平均相 対速度（図 10参照）を用いている。

初めにパラメータ $\alpha_{1}$ と歩行者属性・環境情報の関係について考 察した（図11(a))。 $\alpha_{1}$ はその值が大きいと, 近隣の他者から受け るストレスの距離減衰は大きく, 遠方の歩行者からのストレスはほ とんど影響しなくなる。この $\alpha_{1}$ は情報空間内の密度と最も相関が 高く，密度が上昇すると $\alpha_{1}$ は大きくなる。つまり，密度上昇に伴 い遠方の他者から受けるストレスは相対的に小さくなり，近隣の歩 行者のみに注意を払って歩行するようになる。また，属性別に $\alpha_{1}$ と密度の関係について考察した。密度上昇に対する傾きから, 男性 は女性よりも，また, worker（サラリーマン・OL)は other (worker 以外)よりも，遠方に注意を払って歩行していることがわかる。

次に，図 9 から限界距離は $\alpha_{2} / \alpha_{1}$ で近似できることが判明してい るので， $\alpha_{2} / \alpha_{1}$ と属性の関係について考察した（図11(b)）。図か ら密度が上昇するほど，また，高齢になるほど限界距離が小さくな り他者が十分接近しないと回避行動を取らないことがわかる注6)。

図 10 に示すように, 平均相対速度は歩行者から見た群集流動の 平均的な移動の方向を表している。群集流動が同方向流の場合に は, 平均相対速度は小さくなり, 異方向流の割合が増えると大きく なる。図 11 (b) から異方向流の割合が増え平均相対速度が大きくな ると，限界距離は大きくなり，早めに回避を行うことがわかる。

\section{3 . 3 步行者属性別の步行特性のモデル化}

推定パラメータの值を目的変数, 歩行者属性・環境情報を説明変 数として，重回帰分析を行った。その結果を表 2 に示す。 $\alpha_{1}$ につい ては以下の重回䑐式が得られた。

$$
\alpha_{1}=(-0.2851[\text { worker }]+1.07)[\text { [密度 }]-1.0885
$$

ただし,[worker]はダミー变数である。推定された回帰係数を見 ると, 密度が上昇すると $\alpha_{1}$ も大きくなり, 近隣の歩行者からのス トレスが支配的になることが表れている。また，worker の係数が 負であることから, worker は遠方の歩行者に注意を払って歩行し ていることがわかる。

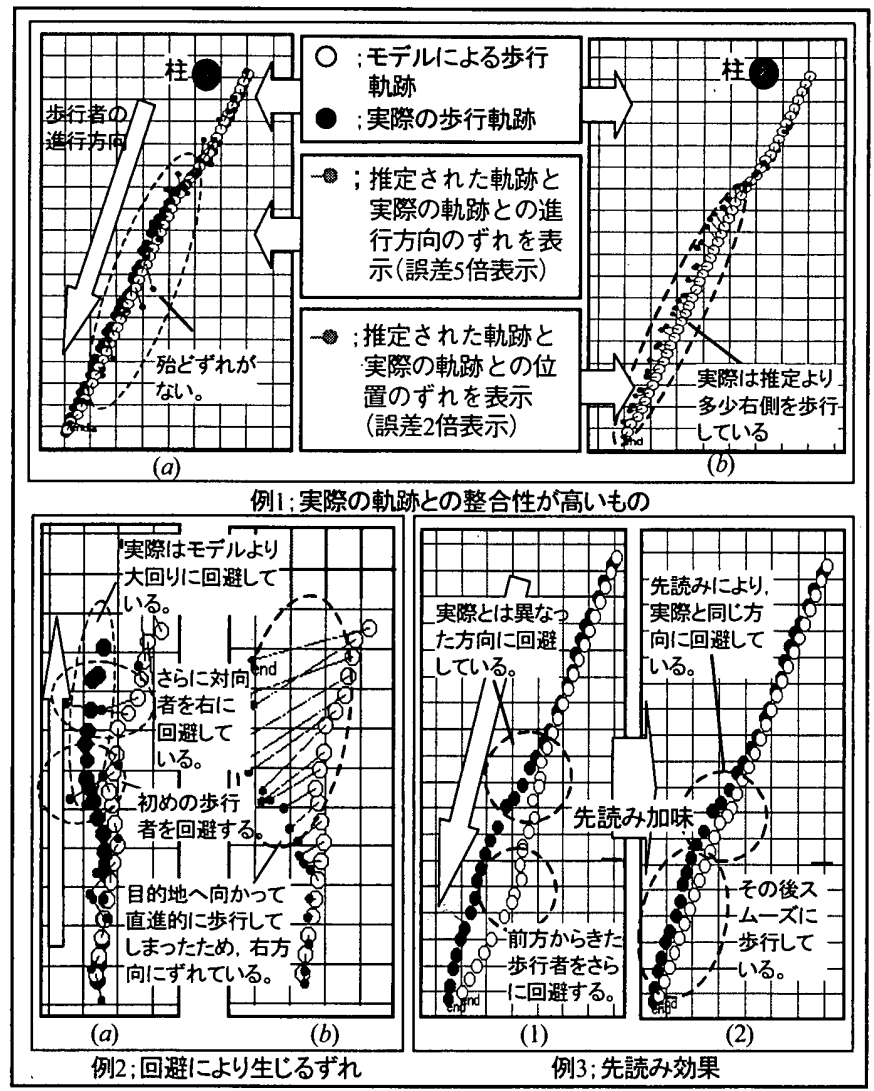

図12 モデルの適合性の検証

次に， $\alpha_{2}, \beta_{1}, \beta_{2}$ を相互に組み合わせて表現される限界距離を 目的変数として重回帰分析を試み, 得られた結果をもとに, 表 $2 に$ 示す要領で $\alpha_{2}, \beta_{1}, \beta_{2}$ を記述するモデルを求めた。まず, 対向者 との限界距離 $\alpha_{2} / \alpha_{1}$ の重回㷌式を以下に示す。

$$
\begin{aligned}
\alpha_{2} / \alpha_{1} & =(0.01084[\text { 男 }]-0.04414[\text { worker }]-0.09670)[\text { 密度 }] \\
& +1.7848[\text { 平均相対速度] }-0.02664[\text { 年齢 }]
\end{aligned}
$$

ただし, [男], [worker] はダミ一变数である。回帰係数が正の值で あると，限界距離が大きくなることを示している。すなわち，回临 係数の大きな説明変数は, 早めに回避行動を行うように作用する変 数である。例えば, 平均相対速度が上昇したり, 情報空間内の密度 が低下すると早めに回避することが回帰係数に表れている。同様 に， $\beta_{1}, \beta_{2}$ の回帰式を表 2 に示した。以下では,これらの回帰式を 組み込んだ歩行モデルを用いる。

\section{3.4 步行モデルの適合性検証}

歩行モデルの適合性を検証するために, 実際の歩行軌跡とモデル によって推定された軌跡との位置のずれを求めた。その結果，各時 点 $(0.3$ 秒間隔) の平均距離誤差が約 $11 \mathrm{~cm}$ という微小な範囲に収 まることを確認した。表 1 に示した平均距離誤差は個人ごとに異な るパラメータを用いた結果であったが,ここでは, 歩行者属性と環 境情報をもとに推定したパラメータの值を用いている点が異なる。 すなわち，モデルとして一般性を高めたにもかかわらず，モデルの 高い記述力は保たれている。

次に, 実際の歩行軌跡と歩行モデルによる歩行軌跡を比較して, 視覚的に適合性を検証した。図 12 の（a）には実際の軌跡とモデル 


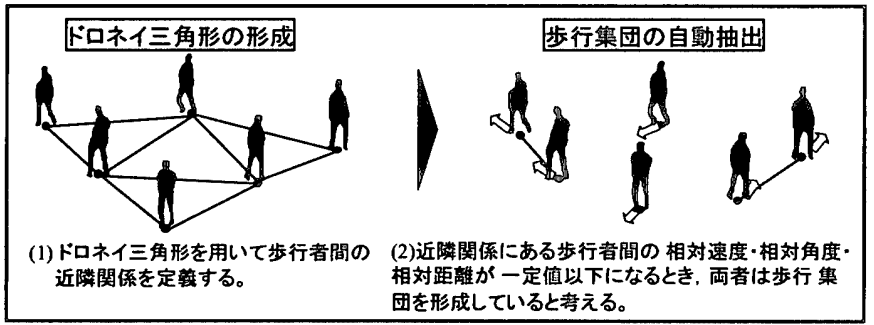

图 13 步行集団の自動抽出方法

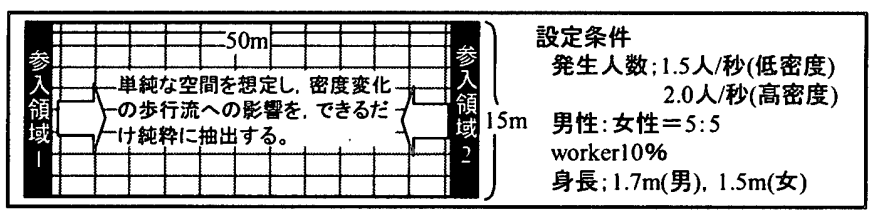

图 14 シミュレーションの設定婪件（そのけ）

の軌跡との進行方向の違いを，(b)には両者の位置のずれを示して ある。少数であるが，実際の歩行軌跡とずれたケースも見られた。 その例を例 2 に示してある。実際の歩行軌跡では後続の対向者を 意識し, 初めの他者を大回りして回避しているのに対し，モデルで は目的地方向に直進している。これは, 実際の歩行者の目的地ス卜 レスがモデルのそれよりも小さかったためと考えられる。しかし， 全体的には例 1 のように実際の歩行軌跡とほほ同じ軌跡をたどっ ているケースが多く，モデルの記述力は概して良好である。

例 3 には先読み効果の一例を示した。先読みを加味しない場合 （1）では，実際とは異なる方向に対向者を回避し，その後，前方か らきた対向者を回避している。これに対し，先読みを加味する場合 （2）では，実際と同じ方向に回避し，その後もスムーズに歩行して いる。すなわち，実際の歩行者をモデル化する上で先読み行動を組 み込むことの意義は大きい。

\section{4. シミュレーション実験による群集流動分析}

\section{1密度变化による群集流動に関する考察}

密度上昇に伴い小集団（以下，歩行集団）が形成され，これらが 結合して歩行流が発生する。ここに群集流動の大きな特徽がある。 この様子をシミュレーション実験によって観察した。歩行集団の抽 出方法は図 13 に示してある。詳細については佐藤・大佛文13)，文14) を参照されたい。まず，密度が歩行流に及ほす影響をできるだけ純 粋に抽出するため，図14のような単純な歩行空間を考えた。シミ ユレーション結果の一部を図 15 に示してある。図中の線で結ばれ た歩行者同士は歩行集団を表している。密度が上昇するに伴い，集 団が大きくなることがわかる。なかでも，図 15(b)の点線で囲った 歩行集団は大きく成長しており，周辺の対向者はこの集団の境界を なぞるように歩行している様子が見られた。

次に, 属性別に高密度下で 100 時点（30 秒）間のシミュレーシ ヨンを行い, 各時点で形成されている歩行集団の数（図 13(2)に示 した歩行者ペアの数）を求めた。その結果，高齡者の場合を 1.0 と したとき，女性では 1.37, workerでは 1.17，男性では 1.06 とな り，女性は歩行集団を形成しやすく高齢者は形成しにくいことがわ かった注7)。図 16(a)，(b)に女性と高齡者のシミュレーション結果 の一部を示してある。女性のみの場合，進行方向に長い歩行集団を 形成している。これに対し, 高齢者は近隣の歩行者のみと集団を形

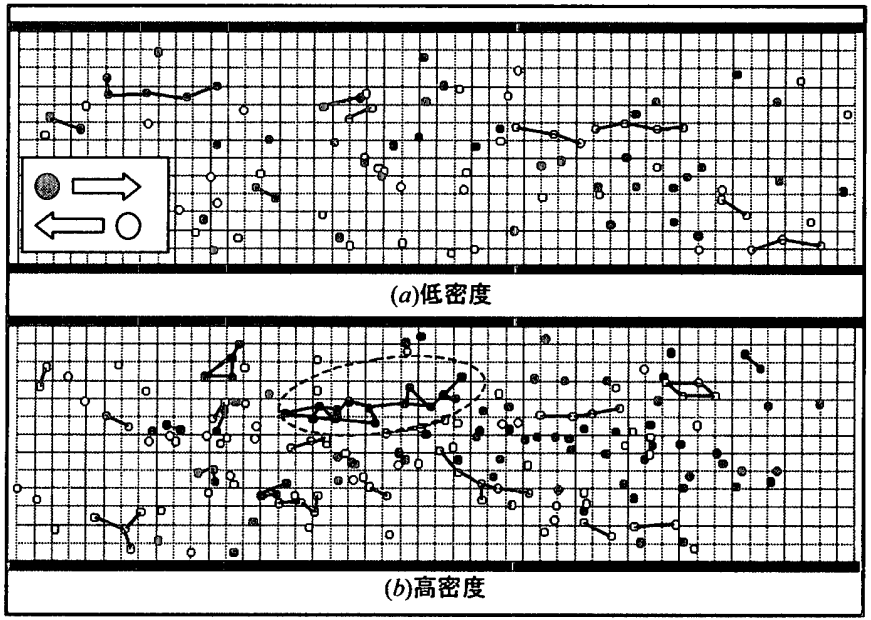

图 15 遙度变化による歩行集団の形成

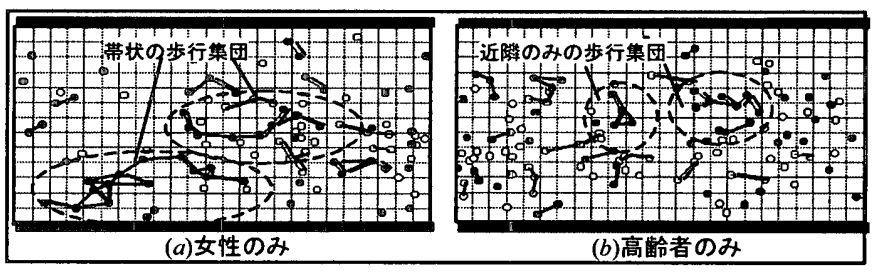

図１６屚性別の歩行集団の発生のしやすさ

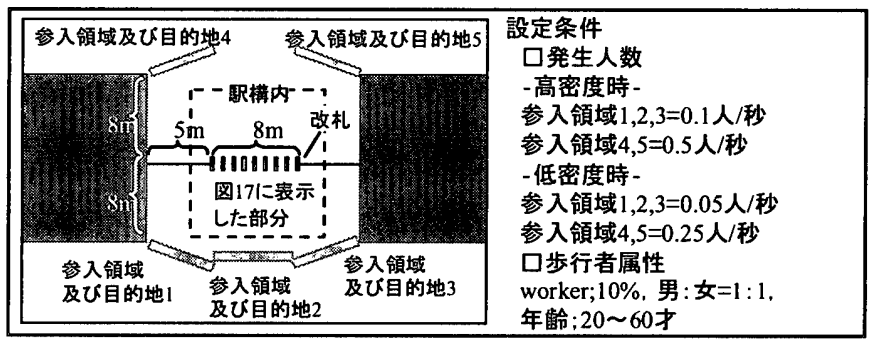

図 17 シミュレーションの設定条件（その2）

成していることがわかる。

\section{2 駅改札口におけるシミュレーション実験}

図 17 に示した改札口周辺の通路空間を分析対象空間として，歩 行モデルを用いて空間分析を行った。また, 歩行時の効率性や快適 性と改札の通過方向との関係について分析するため, 改札への進入 方向のパターンを図18 (1) (a)〜 (d)のように変化させた。さらに， 電車到着による密度変化の影響を考慮して, 歩行者の分析対象領域 への参入の仕方（参入領域の発生人数）を変化させた（図 18 (1) 参入パターン I ・ II )。また, 朝夕の混雑時を想定して, 高密度下 でシミュレーションを行った。

歩行空間を評価する方法として, 目的地にたどり着くまでの到達 時間を全歩行者で平均した値（以下，平均到達時間）と希望到達地 点からのずれ距離（以下，ずれ距離）を用いた。ずれ距離が大きく なるほど, 歩行空間としての快適性は低下するものと考えられる。 図 18 には $25 \mathrm{~cm} \times 25 \mathrm{~cm}$ のグリッド内でずれ距離の平均を求め，そ の空間分布を示してある（図中のドットは $25 \mathrm{~cm} \times 25 \mathrm{~cm}$ のグリッ ドを表しており，色が濃いほど，ずれ距離が大きいことを示してい る)。また，ずれ距離を空間全体で平均した值（以下, 平均ずれ距 離）と平均到達時間についても図中に示してある。

まず，改札の方向が左右に分かれる場合（図18（1）(b)）につい 


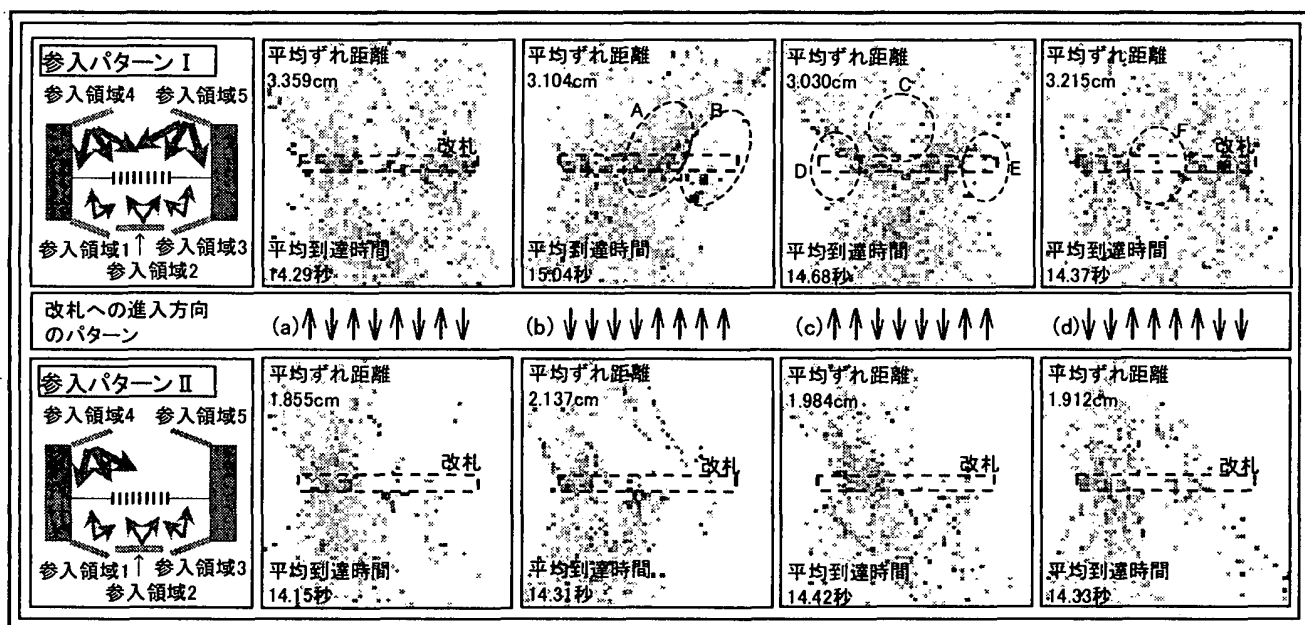

注）ドットの色が漂いほどずれ距離が大きい

(1)高密度時におけるずれ距離

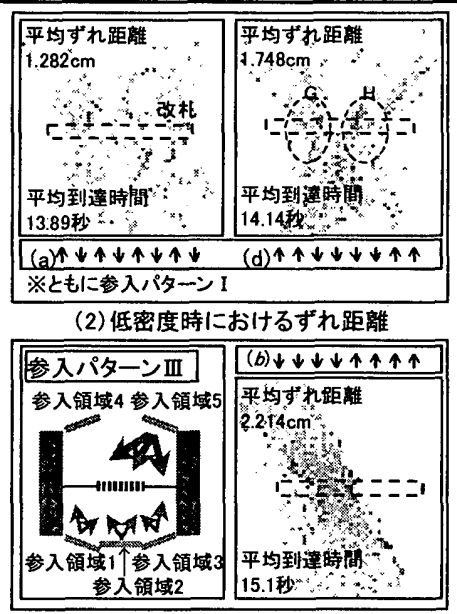

(3)参入パターンIII - 改札パターン(b)

图 18 ずれ距離の空間分布

て考察する。図 18 の A では駅から出る人の流れと駅入入る人の流れ がぶつかり，ずれ距離が非常に大きくなるが，Bでは駅に入る人の同 方向流が形成されるため，ずれ距離が殆ど生じない(快適性が高い)。 平均ずれ距離は参入パターン I ・ II を通して比較的小さい值をとっ ている。しかし，比較対象として設定した参入パターン III（図18(3)） の場合，駅を出る人の流れと駅に入る人の流れが交差するため，平均 到達時間・ずれ距離ともに大きくなってしまう。

次に，改札の方向が交互に入れ替わる場合（a）では，空間全体で ずれ距離が大きくなっている。これは，駅から出る人と駅へ入る人 が隣接して改札を通過するため，改札付近を中心として，空間全体で 群集流動に乱れをもたらしているためである。しかし，平均到達時 間は参入パターン I ・ II ともに最も短く，効率的に歩行者は目的地 にたどり着いている。

最後に , 中央に同方向の改札をまとめた $(\mathrm{c})(\mathrm{d})$ のパターンについ て考察する。図の C, D, E, Fでは，同方向流が形成され，ずれ距離が小 さくなっている。さらに，最も混雑する参入パターンIであっても， (c)の平均ずれ距離は最小值をとっており，最も快適性が高いことが 分かる。また，参入パターンI ・ II を通して $(\mathrm{c})$ のパターンは $(\mathrm{d}) よ$ りもずれ距離が小さい。すなわち，より多くの歩行者（ここでは駅 構内から外へ出る人）が通過する改札を中央にまとめる方が，快適 性は高くなることがわかる。

これらの考察から, 混雑時には, 平均到達時間の効率性を重視す る視点からすれば(a)のパターンが良く，空間の快適性を重視すると (c)のパターンが良いことがわかる。図18（2）には低密度における (a) (c)のパターンのシミュレーション結果を示した。図か.ら (a)の 改札パターンは (c)のパターンよりも平均ずれ距離が小さいことがわ かる。(c)のパターンでは改札の通過方向が入れ替わる付近に歩行者 が集まりやすく，かえって快適性は低減する（図 18(2)のG,H）。つ まり，低密度時では，(a)の改札パターンは効率の面だけでなく快適 性の面でも優れているといえる。

以上より, 電車の発着時刻や密度の変化に応じて, 改札への進入 方向を切り替えることにより快適で効率的な改札空間とすることが 可能となることがわかる。本モデルを用いれば，空間設計のための こうした子細な基礎情報を得ることができる。

\section{5.まとめ}

本研究では，歩行者が歩行中に感じるストレス（他者ストレス と目的地ストレス)を用いて歩行モデルを構築した。また，スト レス概念では直接表現しにくく，ある条件が揃うことで発生する 行動特性についても考察し，歩行モデルに組み込んだ。さらに， 実デー夕をもとにパラメータを推定することで歩行者の歩行特性 と歩行者属性・環境要因との関係を明らかにした。歩行モデルの 検証を試み，歩行者の挙動を良好に表現できることを確認した。 さらに,シミュレーション実験では，個人を記述した歩行モデル であるものの群集流動の特峳である歩行集団の形成を表現できる ことを示した。さらに, 効率性・快適性に着目した歩行空間の環 境評価を試み，本研究で提案した歩行モデルの有用性を示した。

注

1)「情報空間」の大きさは次に示す要領で設定した。①まず,回避行動をとる 歩行者の進行方向を縦方向とする相対座標空間を用意する (図 4 参照), (2すべての回避行動データについて, 文献10)に示した方法で「回避行動 開始時点」を求める,(3)回避行動開始時点における回避する相手の位置を 相対座標空間へプロットする,(4)すべての回避相手の位置を包含する最小 の檍円 (半径 $7 \mathrm{~m}$, 縦横比 $2 \mathrm{~m}$ ) を情報空間とする。以上の手続きで得られる 「情報灴間」の大きさは, 回避行動開始時点(すでに回避相手の存在を意識 している状態)に基づくものであるが, 相対距離の最大値をカバーする空 間範弗を求めることで, 回避相手を意識している「情報空間」を記述でき るものと考えた。

2)「移動可能領域」の大きさは次に示す要領で設定した。(1)注 I) と同様に 相対座標空間を用意する,(2)各歩行者の次時点における自らの位置を相対 座標空間にプロットする, (3)移動可能距離は歩行速度が速い人で大きく遅 い人で小さいことから,(2)で求めた相対座標空間のプロット図を,各歩行 者の希望速度で基準化する，(4)すべての歩行者についてプロット図を重ね 合わせ，ほとんどすべての点が収まる等間範囲(縦方向に希望速度の1.7 倍, 横方向に希望速度の1.4倍の範囲)を「移動可能領域」とする。希望 速度をもとに「移動可能領域」を設定することで,歩行速度の異なる様々 な歩行者について適用することができる。

3)入り乱れた群集流動では,目の前の歩行者が通り過ざるまで立ち止まるこ とがある。本研究で扱うような歩行者密度においては, 1 時点間 $(0.3$ 秒) というわずかな時間内に微小距離だけ移動することは実際的ではなく,わ ずかに進むスペースがあってもその場に瞬間的に静止することの方が自然 である。現時点に対する次時点の移動座標をプロットしてみると, $30 \mathrm{~cm}$ 以 内の移動はほとんど観測されなかった。そこで,この $30 \mathrm{~cm}$ の範囲を立ち 止まり範囲とし，仮にストレス最小地点地点がこの範囲に存在しても，歩 
行者は微小距離を移動せず，現在地点に立ち止まるものと考えた。

4 ) 歩行者 $\mathrm{A}$ の前方を歩行者 Bが歩いているとき,(1)Bの希望速度が $\mathrm{A}$ の希望速 度よりも革く,(2)A-B間の距離が詰まっており,(3) B の進行方向がAの進 行方向とほほ一致していると, A 一時的に歩行速度を高めながら B を追い 越そうとする(追い越し行動開始時点)。追い越し行動の観測された歩行者ぺ アのデータのみを抽出し,追い越し行動開始時点における両者の位圆関係を 回避者(歩行者A)の目的方向をY軸正方向(綎方向)にとった相対座標空間に プロットすると, 縦方向 $4 \mathrm{~m}$, 横方向 $2 \mathrm{~m}$ の棈円に収まることが判明した。ま た，回避者が希望速度で目的方向に向かったときの速度ベクトルと回避相手 の速度ベクトルの差をプロットしてみると,横方向の速度ベクトルの差は $0.2 \mathrm{~m} / \mathrm{s}$ に収まっていることが判明した。以上より，追い越し行動をとる条 件として,図 7 に示すような值を設定した。

5 ) 観測場所の選定に当たっては，(1)歩行者以外の交通や障害物の影響が少ない こと,(2)僱測精度を高めるために,できるだけ高所からビデオ撮影が行える こと,(3)多梯な性別·年齢の歩行者で構成される空間であることなどを勘案 して, 京王·井の頭線·渋谷駅改札前コンコースにおいてビデオ観測調查を 行った。観測時間は, 午前 11 時加 12 時と午後 2 時加 4 時である。歩行 者の身長については柱に設定した目盛をもとに推定した。また,歩行者の性 別やおおよその年龄などについてはビデオ画像を拡大して目視により推定し た。

6 ) 限界距離と推定年齡との相関係数は $1 \%$ 水準で有意であると判定されたが, 強い相関が得られているわけではないので,サンプル数を増やしてより精緻 に検討することが望ましい。また,平均相対速度についても同様である。

7) 各時点における集団を形成している歩行者ぺアの数の平均值は,值の小さい ものから順に，老人が 42.0 , 男性が 44.5 , worker が 49.0 , 女性が 57.5 で あった。これらの值について平均值の差の検定 (サンプル数=100)を試み たところ,各属性間で平均値の差は1\%水準で有意と判定された。

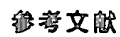

1）中祐一郎：建築の分野に㧍ける歩行研究，鉄道技術研究報告, No. 1079, pp. 115-117, 1978. 3

2) 岡崎甚幸:建築空間に扔ける歩行のためのシミュレーションモデルの研究 (その 1)磁気モデルの応用による歩行モデル, 日本建築学会論文報告集, 第 283 号, pp. 111-117, 1979.9
3)岡崎甚幸:建築空間に扩ける歩行のためのシミュレーションモデルの研究(そ の 2 ) 混雑した場所での歩行一, 日本建築学会論文報告集，第 284 号， pp. 101-110,1979. 10

4 ）建部謙治・中島一: 静止した障害物に対する単独歩行者の回避行動-歩行者 の回避行動に関する研究 (I), 日本建築学会論文報告集, 第418号, pp. 51$57,1990.12$

5 ) 建部謙治, 辻本誠, 志田弘二: 回避行動開始点の判定と前方回避距離-歩行 者の回避行動に関する研究（II），日本建築学会論文報告集，第465号， pp. 95-104, 1994.11

6 ) 矢守克也·杉万俊夫:横断歩道における群集流動の巨視的パターンのシミュ レーション, 実験社会心理学研究，第 32 巻，第 2 号, pp.79-88, 1992

7 ) 岡崎甚幸·松下聡:避難計算のための群集歩行シミユレーションモデルの研 究とそれによる避難安全性の評価，日本建築学会論文報告集，第 436 号， pp. $49-58,1992.6$

8 ) Timms P, Cavalho S: Inclusion of pedestrians and cyclists in network planning models, in Proceedings of the DRIVE Conference Advanced Telematics in Road Transport Reseach, Elsevier Amsterdam, pp.1076-1094, 1991

9) Kerride J., Hine J., Wigan M. : Agent-based modelling of pedestrian movements: the quetions that need to be asked and answered, Environment and Planning B, Vol.28, pp.327-341, 2001

10) 朝田伸剛·大佛俊泰: 歩行者の回避行動に関する研究, 日本建築学会関東支 部研究報告集, pp. 105-108，2001

11) 朝田伸剛·大佛俊泰: 歩行空間における歩行者と自転車の回避行動, 日本建 築築学会大会学術講演梗概集，E-1，pp. 1059-1060,2000

12) 朝田伸剛·大佛俊泰: 自転車と歩行者の回避行動に関する考察, 地理情報シ ステム学会講演論文集,Vol.9, pp. 281-284,2000

13) 佐藤航・大佛俊泰: 群集流動に拈ける歩行集団の抽出方法と視覚化, 日本建 築学会大会学術講演梗概集，E-1，pp. 785-786,2001

14）大佛俊泰·佐藤航：群集流動における歩行集団の抽出方法と視覚化, 地理情報システム学会講演論文集, Vol.10, pp. 189-192,2001

(2003年 4 月 2 日原稿受理, 2003 年 8 月 26 日採用決定) 